\title{
DA INCLUSÃO DAS DESPESAS COM CAPATAZIA NA BASE DE CÁLCULO DO IMPOSTO DE IMPORTAÇÃO: ASPECTOS PRÁTICOS E TEÓRICOS
}

\author{
ABOUT THE INCLUSION OF CAPATAZIA EXPENSES IN THE CALCULATION \\ BASIS OF IMPORT TAX: PRATICAL AND THEORETICAL ASPECTS
}

Pedro Jacob Rodrigues ${ }^{1}$

\section{Resumo}

Este artigo tem por objetivo analisar a legalidade da inclusão das despesas com capatazia na base de cálculo do Imposto de Importação, determinada por Instrução Normativa da Secretaria da Receita Federal. Far-se-á uma análise sob a ótica da Regra Matriz de Incidência Tributária, em especial do seu aspecto temporal; da jurisprudência do Superior Tribunal de Justiça; e dos tratados internacionais contra bitributação. O final do trabalho será dedicado a questões relacionadas à identificação das despesas com capatazia e ao procedimento para cálculo do valor a ser restituído.

Palavras-chave: ilegalidade, despesas com capatazia, imposto de importação.

\section{Abstract}

The purpose of this article to analyze the legality of the inclusion of capatazia expenses in the calculation basis of the Import Tax, determined by a Normative Instruction of the Federal Revenue Secretariat. An analysis will be made from the point of view of the Main Rule of Tax Incidence, especially in its temporal aspect; of the jurisprudence of the Superior Court of Justice; and of the international treaties against double taxation. The end of the work will be devoted to issues related to the identification of the capatazia expenses and to the procedure to calculate the amount to be refunded.

Key words: illegality, capatazia expenses, import tax.

\footnotetext{
1 Advogado e Consultor Tributário. Especialista em Direito Tributário pelo Instituto Brasileiro de Direito Tributário (IBDT). Mestrando em Direito Constitucional e Processual Tributário na Pontifícia Universidade Católica de São Paulo (PUC-SP). Tem experiência em advocacia pública e privada, com ênfase em Direito Tributário. E-mail: rodriguespedrojacob@gmail.com
} 


\section{SUMÁRIO}

Introdução. 1. Dos tratados internacionais enquanto fontes do Direito Tributário. 2. Do aspecto temporal da regra matriz de incidência tributária. 3. A questão das despesas com capatazia. Considerações Finais. Referências.

\section{INTRODUÇÃO}

O presente artigo tem por escopo analisar a questão da inclusão das despesas com capatazia na base de cálculo do Imposto de Importação tendo em vista que o parágrafo $3^{\circ}$ do art. $4^{\text {o }}$ da Instrução Normativa n $^{\circ} 327 / 2003^{2}$, da Secretaria da Receita Federal, dispõe que tais despesas compõem o valor aduaneiro, e este é a base de cálculo do Imposto de Importação.

Para tanto será necessário fazer um estudo que se iniciará nas fontes do Direito, tanto sob a ótica da Teoria Geral do Direito, quanto sob a ótica do Direito Tributário, para sustentar que os tratados internacionais assinados pelo Governo brasileiro são fontes formais do Direito Tributário, e em seguida verificar as possíveis soluções dadas pela doutrina diante de conflitos entre tratados e leis internas.

Em seguida, far-se-á um estudo da Regra Matriz de Incidência Tributária, dando enfoque especial ao seu critério temporal, visto que para a boa resolução da questão ora examinada é fundamental que se identifique o exato momento do surgimento da relação jurídico-tributária.

Por fim, iremos tratar da questão da inclusão das despesas com capatazia na base de cálculo do Imposto de Importação. Explicaremos como se deu o seu surgimento, exporemos o nosso entendimento a partir da doutrina utilizada no trabalho; indicaremos as leis e os decretos fundamentais para resolução da questão; demonstraremos o entendimento jurisprudencial acerca da temática e por fim, trataremos das questões relacionadas à identificação das despesas com capatazia e ao procedimento para cálculo do valor a ser restituído.

\footnotetext{
${ }^{2}$ Instrução Normativa no $327 / 2003$, art. $4^{\circ}$ : "Na determinação do valor aduaneiro, independentemente do método de valoração aduaneira utilizado, serão incluídos os seguintes elementos:

I - o custo de transporte das mercadorias importadas até o porto ou aeroporto de descarga ou o ponto de fronteira alfandegado onde devam ser cumpridas as formalidades de entrada no território aduaneiro;

II - os gastos relativos a carga, descarga e manuseio, associados ao transporte das mercadorias importadas, até a chegada aos locais referidos no inciso anterior; e

III - o custo do seguro das mercadorias durante as operações referidas nos incisos I e II

(...)

$\S 3^{\circ}$ Para os efeitos do inciso II, os gastos relativos à descarga de mercadoria do veículo de transporte internacional no território nacional serão incluídos no valor aduaneiro, independentemente da responsabilidade pelo ônus financeiro e da denominação adotada".
} 


\section{DOS TRATADOS INTERNACIONAIS ENQUANTO FONTES DO DIREITO TRIBUTÁRIO}

Há uma série de divergências doutrinais acerca das fontes do Direito e sobre esta não iremos tratar aqui, visto que fugiria ao escopo do presente trabalho. Faz-se importante ressaltar, todavia, que adotaremos a doutrina de Maria Helena Diniz, ao invocar a Teoria Egológica de Carlos Cossio (DINIZ, 2017, p. 300), que demonstrou que o jurista deve ater-se tanto às fontes materiais como às formais, preconizando a supressão desta distinção, preferindo falar em fonte formal-material, já que toda fonte formal contém, de modo implícito, uma valoração, que só pode ser compreendida como fonte do direito no sentido de fonte material.

A autora baseia-se nas ideias de Luiz Fernando Coelho para dispor que a fonte material ou real apontaria a origem do Direito, configurando a sua gênese. Portanto seria fonte de produção, aludindo a fatores éticos, sociológicos, históricos, políticos, etc., que produziriam o Direito, condicionariam o seu desenvolvimento e determinariam o conteúdo das normas. Enquanto a fonte formal lhe daria forma, fazendo referência aos modos de manifestação das normas jurídicas, demonstrando quais os meios empregados pelo jurista para conhecer o Direito, ao indicar os documentos que revelam o Direito vigente, possibilitando sua aplicação a casos concretos, apresentando-se, portanto, como fonte de cognição. As fontes formais seriam, ainda, os modos de manifestação do Direito mediante os quais o jurista conhece e descreve o fenômeno jurídico. Logo, quem quisesse conhecer o Direito deveria buscar a informação desejada nas suas fontes formais, que seriam a lei, os arquivos de jurisprudência e os tratados doutrinários. (COELHO apud DINIZ, 2017, p. 300-3001).

Devemos destacar que discordamos da autora quando defende a doutrina como fonte do Direito, visto que não há criação do Direito, pois, conforme dispõe Miguel Reale, não há positivação de regra jurídica, com vigência e eficácia no contexto de uma estrutura normativa. (REALE, 2002, p. 139).

É por isso que trazemos à lume as ideias de Hans Kelsen quando este leciona que a aplicação do Direito é, simultaneamente, produção do Direito. De acordo com o mencionado doutrinador estes dois conceitos não representam uma oposição, é desacertado distinguir atos de criação e atos de aplicação do Direito. Todo ato jurídico é, simultaneamente, aplicação de uma norma superior e produção, regulada por esta norma, de uma norma inferior. Explica o autor que, por aplicação da Constituição, opera-se a criação das normas jurídicas gerais através 
da legislação e do costume; e, em aplicação destas normas gerais, realiza-se a criação das normas individuais através das decisões judiciais e das resoluções administrativas. Somente a execução do ato coercitivo estatuído por estas normas individuais (o último ato do processo da produção jurídica) se opera em aplicação das normas individuais que a determinam sem que seja, ela própria, criação de uma norma. A aplicação do Direito é, por conseguinte, criação de uma norma inferior com base numa norma superior ou execução do ato coercitivo estatuído por uma norma. (KELSEN, 1998, p. 164).

Portanto, não se pode falar em fonte do Direito se não houver criação, seja pela gênese normativa em si, expressão do Poder Legislativo; seja pela aplicação da lei, expressão do Poder Judiciário; seja pelos usos e costumes, expressão do poder social e fonte do Direito por determinação legal; seja pela fonte negocial, expressão da autonomia da vontade.

No que tange especificamente às fontes do Direito Tributário, o Código Tributário Nacional dispôs em seu art. 96, que a expressão "legislação tributária" compreenderia as leis, os tratados e as convenções internacionais, os decretos e as normas complementares que versem, no todo ou em parte, sobre tributos e relações jurídicas a eles pertinentes. ${ }^{3}$ Entendemos que o art. 96 não teve a pretensão de esgotar tudo o que poderia ser tido por fonte no Direito Tributário, mas apenas explanar o que comporia a expressão "legislação tributária".

Não iremos tratar de todas as fontes do Direito Tributário previstas no supracitado dispositivo do Código Tributário Nacional. Para os fins almejados pelo presente trabalho é importante destacar apenas que não pode haver dúvidas de que os tratados internacionais são fonte do Direito Tributário.

Para Paulo Dourado de Gusmão, tratado internacional é o acordo por escrito entre Estados soberanos, contentado regras gerais disciplinadoras de suas relações e de seu posicionamento a respeito de determinada questão. Por vezes também pode ser denominado convenção, pacto ou convênio internacional, estabelece norma de validez internacional circunscrita aos países que o celebrarem. Destaca o autor que têm sido feitas distinções, sem grande alcance, no gênero tratado: tratado, quando tiver conteúdo político (tratado de aliança, de não agressão, de paz, de neutralidade, e etc.); pacto, com conteúdo político mais restrito; convenção, de natureza econômica, judiciaria ou de direito privado; acordo, de natureza comercial; e concordata, com a Igreja. Adotaremos, para o presente trabalho, o gênero tratado

\footnotetext{
${ }^{3}$ Código Tributário Nacional: "Art. 96. A expressão "legislação tributária" compreende as leis, os tratados e as convenções internacionais, os decretos e as normas complementares que versem, no todo ou em parte, sobre tributos e relações jurídicas a eles pertinentes”.
} 
internacional para tratar de modo genérico, tanto dos tratados relativos a tributos aduaneiros e acordos de bitributação quanto dos compromissos assumidos pelo País em órgãos colegiados de comércio, pois de acordo com Luís Eduardo Schoueri, ambos assumem papel relevante. (GUSMÃO, 2015, p. 139-140); (SCHOUERI, 2017, p. 108).

Luís Eduardo Schoueri adverte sobre a má técnica legislativa em que incorreu o art. 98 do Código Tributário Nacional ${ }^{4}$, ao prever que os tratados e as convenções internacionais revogam ou modificam a legislação tributária interna, e serão observados pela as que lhes sobrevenha, pois o problema não é obviamente de revogação, mas de observância. Haja vista que, se fosse verdadeiro que um tratado revoga a lei interna, então, o que poderíamos dizer das hipóteses em que o tratado é denunciado? Não poderíamos aplicar a lei interna?

Entende-se que, se a lei interna houvesse sido revogada pelo tratado, ela não poderia voltar a ser aplicada após a denúncia do referido diploma, pois o ordenamento jurídico brasileiro não adotou a figura da repristinação. Mais correto seria entender que a denúncia do tratado apenas retira a barreira limitadora da aplicação da lei interna. O importante, neste ponto, é entender que a função do tratado é firmar os limites do exercício da jurisdição brasileira. Neste papel, deve ser observado pela legislação interna, que apenas atua dentro de tais limites. (SCHOUERI, 2017, p. 109).

Neste ponto, não podemos deixar de falar sobre as teorias que cuidam do conflito entre as normas provenientes dos tratados e as normas do sistema jurídico interno dos Estados. Para a teoria monista, uma vez firmado, o tratado internacional ingressa de imediato na ordem jurídica interna do Estado contratante. O monismo divide-se, ainda, em duas correntes: a primeira afirma a supremacia do tratado internacional em face do Direito interno e a segunda afirma valer o Direito interno em caso de conflito. Para a teoria dualista a ordem interna e a ordem internacional têm coexistência independente, não se podendo, a princípio, falar em conflito entre elas. Dispõe, ainda, o dualismo que, para que as normas internacionais possam valer na esfera interna é necessário que ela passe por processo de recepção para transformar-se em norma jurídica do sistema jurídico do Estado. (NUNES, 2016, p. 134).

No que tange à relação entre o disposto em um tratado internacional e a lei interna, podemos trazer a lume a explicação figurativa da máscara do professor alemão Klaus Vogel (VOGEL, 2017, p. 125-126), que ensina que os acordos de bitributação servem como uma máscara, colocada sobre o direito interno, tapando determinadas pares deste, de forma que os

\footnotetext{
${ }^{4}$ Código Tributário Nacional: "Art. 98. Os tratados e as convenções internacionais revogam ou modificam a legislação tributária interna, e serão observados pela que lhes sobrevenha".
} 
dispositivos de direito interno que continuarem visíveis (por corresponderem aos buracos recortados no cartão) são aplicáveis, enquanto os demais não.

A conclusão que se chega a partir desse raciocínio é de que é lícito ao jurista examinar o direito interno ou o acordo de bitributação, conforme o caso prático revelar mais fácil. E que somente quando da existência de uma norma de Direito Tributário interno, prevendo a incidência tributária no caso em análise e, cumulativamente, da ausência de norma de acordo de bitributação excluindo aquela tributação, é que se pode concluir pelo nascimento da obrigação tributária no caso concreto. (SCHOUERI, 2017, p. 126).

Devemos destacar, todavia, que não há unanimidade na doutrina quanto à hierarquia dos tratados contra a bitributação em relação à legislação interna. Alexandre Luiz Moraes do Rêgo Monteiro (MONTEIRO, 2016, P. 40-41), juntamente com parte relevante da doutrina entendem que as normas veiculadas por meio de tratado seriam dotadas de status diferenciado, tal como devidamente estabelecido pelo art. 98 do Código Tributário Nacional.

Ricardo Maitto da Silveira também entende que, por força dos princípios de Direito Internacional Público, consubstanciados na própria Convenção de Viena ${ }^{5}$, os acordos têm prevalência sobre o Direito interno, não podendo os países signatários invocar as disposições de suas legislações para justificar o inadimplemento dos acordos. (MAITTO, 2016, p. 32).

Alexandre Luiz Moraes do Rêgo Monteiro destaca, entretanto, que independentemente da posição hierárquica dos tratados, que se reconhece privilegiada em relação à ordem interna, deve-se ressaltar o entendimento doutrinário no sentido de que as regras previstas nos acordos de bitributação consistiriam em limitações à aplicação da legislação interna, na medida em que, muito embora não revogando ou alterando a legislação, impediriam a sua eficácia especificamente em relação às situações abrangidas pelos referidos acordos. (MONTEIRO, 2016, p. 41).

O mencionado autor, mesmo que representante de doutrina que entende haver hierarquia entre os tratados e a legislação interna, concorda com a aplicação da teoria de Klaus Vogel no sentido que de que os acordos de bitributação seriam limitações à aplicação da legislação interna de forma que, em um primeiro momento, e para os fins do presente trabalho, as decorrências práticas seriam as mesmas, independentemente da corrente doutrinaria adotada.

\footnotetext{
${ }^{5}$ A Convenção de Viena sobre o Direito dos Tratados prevê: “Artigo 26. Todo tratado em vigor obriga as partes e deve ser cumprido por elas de boa fé". "Artigo 27. Uma parte não pode invocar as disposições de seu direito interno para justificar o inadimplemento de um tratado".
} 


\section{DO ASPECTO TEMPORAL DA REGRA MATRIZ DE INCIDÊNCIA TRIBUTÁRIA}

Partiremos agora para um dos pontos fulcrais deste trabalho, e que será essencial para a boa explicação do caso prático do qual trataremos no tópico seguinte. Iremos explorar a doutrina daqueles que se comprometeram a estudar a regra-matriz de incidência tributária, dando enfoque especial à doutrina de Paulo de Barros Carvalho, autor precursor do tema.

A norma tributária em sentido estrito é a que define a incidência fiscal. Sua construção é obra do cientista do Direito e se apresenta, de final, com a compostura própria dos juízos hipotéticos condicionais. Haverá uma hipótese, suposto ou antecedente a que se conjuga um mandamento, uma consequência ou estatuição. A forma associativa é a cópula deôntica, o dever-ser que caracteriza a imputação jurídico-normativa. Assim, para obter-se o vulto abstrato da regra-matriz é mister isolar as proposições em si, como formas de estrutura sintática; suspender o vetor semântico da norma para as situações objetivas; ao mesmo tempo em que se desconsidera atos psicológicos de querer e de pensar a norma. (CARVALHO, 2015, p. 239).

Dentro desse arcabouço, a hipótese trará a previsão de um fato (se alguém importar produtos), enquanto a consequência prescreverá a relação jurídica (obrigação tributária) que se vai instaurar, onde e quando acontecer o fato cogitado no suposto (aquele alguém deverá pagar à Fazenda Federal de 0 a 35\% - a depender do produto - do valor do produto importado). A hipótese alude a um fato e a consequência prescreve os efeitos jurídicos que o acontecimento irá propagar, razão pela qual se fala em descritor e prescritor, o primeiro para designar o antecedente normativo e o segundo para indicar seu consequente. (CARVALHO, 2015, p. 239).

Para o mencionado doutrinador, a despeito das críticas dos modernos cientistas do Direito Tributário, que têm insistido na circunstância de que, tanto no descritor (hipótese) quanto no prescritor (consequência) existem referências a critérios, aspectos, elementos ou dados identificativos, dispõe que na hipótese (descritor), deve-se encontrar um critério material (comportamento de uma pessoa), condicionado no tempo (critério temporal) e no espaço (critério espacial), e que já na consequência (prescritor), deve-se encontrar um critério pessoal (sujeito ativo e sujeito passivo) e um critério quantitativo (base de cálculo e alíquota). E com a conjunção desses dados indicativos teremos a possibilidade de exibir, a sua plenitude, o núcleo lógico-estrutural da norma-padrão de incidência tributária. (CARVALHO, 2015, p. 239). 
Para tornar o assunto mais palatável optamos por trazer um exemplo de aplicação da regra-matriz de incidência pensado pelo próprio Paulo de Barros Carvalho, qual seja, no caso da incidência do IPI na importação de produtos industrializados. A regra-matriz ficaria composta da seguinte forma, na hipótese: o critério material seria importar produto industrializado; o critério espacial seriam as repartições alfandegárias do país; e o critério temporal seria o momento do desembaraço aduaneiro. Na consequência: o critério pessoal seria composto pelo sujeito ativo (União) e pelo sujeito passivo (importador); o critério quantitativo seria composto pela base de cálculo (o valor que servir de base para o cálculo dos tributos aduaneiros, acrescido do montante desses e dos encargos cambiais devidos pelo importador) e pela alíquota (percentagem constante da tabela). (CARVALHO, 2015, p. 239).

Para a consecução das finalidades almejadas pelo presente trabalho, todavia, devemos nos aprofundar apenas em dois critérios da regra-matriz de incidência, um destes previstos no antecedente e o outro no consequente, quais sejam: o critério temporal e o critério quantitativo, pois são estes que provocam interpretação divergente entre fisco e contribuinte no caso que examinaremos no tópico seguinte.

Nos utilizaremos da doutrina de Renato Lopes Becho para explicar o critério temporal da regra-matriz da norma jurídico-tributária. Para o autor este é o critério que estipula o momento em que o critério material, em ocorrendo, fará surgir a relação jurídico-tributária entre contribuinte e Fisco. Dispõe que, como o critério material é a expressão hipotética de um acontecimento fático, esse fato tem de ter uma descrição de tempo, que o situe em coordenadas temporais (hora, dia, mês e ano). (BECHO, 2015, p. 133).

Ocorre que, por vezes, o critério temporal pode ser mais complexo do que aparenta ser em um primeiro momento. Pode exemplificar-se com o Imposto de Importação, exação cujo critério temporal é dos mais difíceis para o intérprete, pois ele tem que refletir os critérios anteriores, ou seja, tem que ser o momento em que os produtos ingressam no território nacional. Para melhor explicar o tema o autor utiliza-se de lições de Gaston Jéze que dispõe que, no que tange aos impostos alfandegários o fato gerador do imposto é a passagem de mercadorias pela fronteira, seja para importação, seja para exportação. Esse fato material de passagem é a ocasião fixada pela lei para exercer determinado adiantamento sobre o valor daqueles bens. (JÉZE apud BECHO, 2015, p. 133-134).

$\mathrm{O}$ art. 19 do Código Tributário Nacional dispõe que o imposto, de competência da União, sobre a importação de produtos estrangeiros tem como fato gerador a entrada destes no 
território nacional. ${ }^{6}$ A té este ponto não parece ter problema, tendo em vista que o entendimento da doutrina vai ao encontro do que dispõe a lei.

O Decreto-Lei n 37 de 1966 dispõe de modo semelhante em seu art. $1^{\circ}$, caput, no qual determina que o fato gerador da Imposto de Importação é a entrada da mercadoria no território nacional. No entanto, há uma questão problemática, para a qual Renato Lopes Becho chama atenção, que é o texto do $\S 2^{\circ}$ do art. $1^{\circ 7}$ que dispõe que, para efeito de ocorrência do fato gerador, considerar-se-á entrada no território nacional a mercadoria que constar como tendo sido importada e cuja falta venha a ser apurada pela autoridade aduaneira. (BECHO, 2015, p. 134).

Isso leva à interpretação de que o critério temporal do indigitado imposto é o desembaraço aduaneiro, atividade administrativa que tem por objeto a referida constatação, interpretação reforçada pelo art. 23 e seu parágrafo único ${ }^{8}$, que dispõe, em suma, que quando se tratar de mercadoria despachada para consumo, considera-se ocorrido o fato gerador na data do registro, na repartição aduaneira, da declaração a que se refere o art. $44^{9}$. Esta declaração, por sua vez, será o documento no qual o despacho aduaneiro de mercadoria importada irá se basear. (BECHO, 2015, p. 135).

O Supremo Tribunal Federal já tem entendimento sumulado a esse respeito ${ }^{10}$ dando a entender que não haveria vício de inconstitucionalidade na questão acima descrita. Dessa forma, apesar de a questão poder gerar inconsistências no caso concreto, não seria frutífero aprofundar este debate, visto já ser unânime na jurisprudência que o desembaraço aduaneiro é o critério material do imposto de importação.

\footnotetext{
${ }^{6}$ Código Tributário Nacional: "Art. 19. O imposto, de competência da União, sobre a importação de produtos estrangeiros tem como fato gerador a entrada destes no território nacional."

${ }^{7}$ Decreto-Lei $n^{\circ} 37$ de 1966: "Art. $1^{\circ}$. O Imposto sobre a Importação incide sobre mercadoria estrangeira e tem como fato gerador sua entrada no Território Nacional. $\S 1^{\circ}$. Para fins de incidência do imposto, considerar-se-á também estrangeira a mercadoria nacional ou nacionalizada exportada, que retornar ao País, salvo se: a) enviada em consignação e não vendida no prazo autorizado; b) devolvida por motivo de defeito técnico, para reparo ou substituição; c) por motivo de modificações na sistemática de importação por parte do país importador; d) por motivo de guerra ou calamidade pública; e) por outros fatores alheios à vontade do exportador. $\S 2^{\circ}$. Para efeito de ocorrência do fato gerador, considerar-se-á entrada no Território Nacional a mercadoria que constar como tendo sido importada e cuja falta venha a ser apurada pela autoridade aduaneira."

${ }^{8}$ Decreto-Lei $\mathrm{n}^{\circ} 37$ de 1966: "Art. 23. Quando se tratar de mercadoria despachada para consumo, considera-se ocorrido o fato gerador na data do registro, na repartição aduaneira, da declaração a que se refere o artigo 44".

${ }^{9}$ Decreto-Lei $\mathrm{n}^{\circ} 37$ de 1966: "Art.44 - Toda mercadoria procedente do exterior por qualquer via, destinada a consumo ou a outro regime, sujeita ou não ao pagamento do imposto, deverá ser submetida a despacho aduaneiro, que será processado com base em declaração apresentada à repartição aduaneira no prazo e na forma prescritos em regulamento".

${ }^{10}$ A Súmula 661 do Supremo Tribunal Federal dispõe que "Na entrada de mercadoria importada do exterior, é legítima a cobrança do ICMS por ocasião do desembaraço aduaneiro".
} 
Destacamos, todavia, para fins acadêmicos a opinião de Renato Lopes Becho que dispõe que desembaraço aduaneiro pode ser o critério temporal para alguma taxa de serviço aduaneiro, mas nunca do Imposto de Importação. Pois não seria compatível com a Constituição a esdrúxula situação de termos dois bens, um ao lado do outro, os dois em aduana nacional e, por um deles ter recebido uma vistoria de um fiscal público, ser considerado importado, e o outro, ao lado (mesmo que tenha ingressado no País antes daquele), não tendo recebido a vistoria, não ser considerado importado. Ou o tributo é sobre a vistoria, ou é sobre o ingresso do bem no território nacional. (BECHO, 2015, p. 135).

Tendo esclarecido o necessário acerca dos tratados internacionais enquanto fonte do Direito Tributário, bem como acerca do aspecto temporal da regra-matriz, faremos uma breve análise de legalidade para que depois possamos analisar mais detidamente a questão das despesas com capatazia.

Apesar de não ser foco do presente artigo fazer uma análise de legalidade da questão da inclusão das despesas com capatazia na base de cálculo do Imposto de Importação, faz-se importante ressaltar que este é um forte argumento a ser oposto perante a pretensão do fisco. Trataremos, dessa forma, brevemente sobre o mencionado princípio.

O constituinte originário preocupou-se em dispor, dentre os direitos e garantias fundamentais, previstos no art. $5^{\circ}$, que ninguém será obrigado a fazer ou deixar de fazer alguma coisa senão em virtude de lei. A previsão está no inciso II, que encerra um dispositivo fundamental que impede que o Estado aja com arbítrio em suas relações com o indivíduo, que, afinal, tem o direito de fazer tudo quanto a lei não lhe proíbe. (CARRAZZA, 2015, p. 262).

Já no artigo 150, I, da Constituição Federal o legislador, empenhado em acautelar direitos dos contribuintes dispôs que: sem prejuízo de outras garantias asseguradas ao contribuinte, é vedado à União, aos Estados, ao Distrito Federal e aos Municípios exigir ou aumentar tributo sem lei que o estabeleça. Reforçando, desta forma, a intensidade do princípio da legalidade no campo tributário e de maneira a deixar claro que qualquer exação deve ser instituída ou aumentada não simplesmente com base em lei, mas pela própria lei e diretamente dela. (CARRAZZA, 2015, p. 264-265).

Está tratada, assim, na Constituição Federal, a legalidade tributária. Devemos destacar, novamente, a doutrina de Luís Eduardo Schoueri, que faz uma comparação entre o texto do art. $5^{\circ}$, II, com o texto do art. 150 , I e percebe que o constituinte não foi redundante quando tratou da matéria tributária, pois se, em geral, um comportamento será exigido "em virtude" de uma 
lei, nas questões tributárias, tem-se a exigência de a obrigação estar prevista na própria lei. Não há espaço para delegação. Será a lei o fundamento imediato da exigência. Ao legislador cumpre definir o antecedente e o consequente da norma tributária. $\mathrm{O}$ autor denomina reserva de lei a característica de que decorre da comparação do art. 150, I com o art. $5^{\circ}$, II da Constituição Federal. Enquanto este tolera a delegação, a reserva de lei implica que somente a lei (ela mesma) é que institui ou majora tributo. (SCHOUERI, 2017, p. 310-311).

Devemos concluir, a partir desta breve exposição, que a inclusão das despesas com capatazia na base de cálculo do Imposto de Importação fere o Princípio da Legalidade, tendo em vista que a base de cálculo constitui elemento da reserva legal e apenas uma lei, em sentido formal, poderia alterar o conceito de valor aduaneiro, que é base de cálculo do Imposto de Importação.

\section{A QUESTÃO DAS DESPESAS COM CAPATAZIA}

Fizemos uma exposição teórica acerca dos tratados internacionais enquanto fonte do Direito Tributário, bem como do aspecto temporal da regra-matriz de incidência tributária. Podemos, agora, tratar de uma forma mais minuciosa da questão das despesas com capatazia.

O parágrafo $3^{\circ}$ do art. $4^{\circ}$ da Instrução Normativa $n^{\circ} 327 / 2003$, da Secretaria da Receita Federal, dispõe que na determinação do valor aduaneiro, independentemente do método de valoração aduaneira utilizado, serão incluídos os gastos relativos à descarga da mercadoria do veículo de transporte internacional no território nacional no valor aduaneiro, independentemente da responsabilidade pelo ônus financeiro e da denominação adotada. ${ }^{11}$

No entanto, há previsão no Decreto $n^{\circ} 6.759$ que a base de cálculo do Imposto de Importação é o valor aduaneiro, e o art. $77^{12}$ determina que deve compor o valor aduaneiro o

\footnotetext{
${ }^{11}$ Instrução Normativa no 327/2003, art. 4": "Na determinação do valor aduaneiro, independentemente do método de valoração aduaneira utilizado, serão incluídos os seguintes elementos:

I - o custo de transporte das mercadorias importadas até o porto ou aeroporto de descarga ou o ponto de fronteira alfandegado onde devam ser cumpridas as formalidades de entrada no território aduaneiro;

II - os gastos relativos a carga, descarga e manuseio, associados ao transporte das mercadorias importadas, até a chegada aos locais referidos no inciso anterior; e

III - o custo do seguro das mercadorias durante as operações referidas nos incisos I e II

(...)

$\S 3^{\circ}$ Para os efeitos do inciso II, os gastos relativos à descarga de mercadoria do veículo de transporte internacional no território nacional serão incluídos no valor aduaneiro, independentemente da responsabilidade pelo ônus financeiro e da denominação adotada".

12 Decreto $n^{\circ}$ 6.759, art. 77: "Integram o valor aduaneiro independentemente do método de valoração utilizado (Acordo de Valoração Aduaneira, Artigo 8, parágrafos 1 e 2, aprovado pelo Decreto Legislativo no 30, de 1994, e promulgado pelo Decreto ${ }^{0} 1.355$, de 1994; e Norma de Aplicação sobre a Valoração Aduaneira de Mercadorias, Artigo 7을 aprovado pela Decisão CMC no 13, de 2007, internalizada pelo Decreto $\mathrm{n}^{\circ} 6.870$, de 4 de junho de 2009):(Redação dada pelo Decreto $n^{\circ} 7.213$, de 2010).
} 
custo de transporte da mercadoria importada até o porto ou o aeroporto alfandegado de descarga ou o ponto de fronteira alfandegado onde devam ser cumpridas as formalidades de entrada no território aduaneiro; os gastos relativos à carga, à descarga e ao manuseio, associados ao transporte da mercadoria importada até a chegada aos locais referidos acima; e o custo do seguro da mercadoria durante a operação de importação.

Podemos perceber que toda espécie de gasto que deverá compor o valor aduaneiro só poderá ser considerada até determinado ponto, até determinado momento, que é quando devem ser cumpridas as formalidades de entrada da mercadoria no território aduaneiro. Essa constatação nos leva à conclusão inexorável de que não deverá incidir qualquer outro custo que não os indicados no artigo antecedente, que dispõe de forma exaustiva sobre estes.

Todavia, para superar qualquer dúvida a este respeito, o legislador do mencionado decreto estabeleceu, no art. $79^{13}$, aquilo que não deverá ser considerado para fins de composição do valor aduaneiro, determinando expressamente que os gastos associados ao transporte, incorridos no território aduaneiro a partir do porto ou aeroporto alfandegado de descarga ou o ponto de fronteira alfandegado onde devam ser cumpridas as formalidades de entrada no território aduaneiro não integram o valor aduaneiro.

Dessa forma, não restam dúvidas de que os valores incorridos a título de despesas com capatazia não devem integrar a base de cálculo do Imposto de Importação já que esta, nos termos do art. 40, parágrafo $1^{\circ}$, I, da Lei $\mathrm{n}^{\mathrm{o}} 12.815$ de $2013^{14}$, a capatazia nada mais é que a atividade de movimentação de mercadorias nas instalações dentro do porto, o que compreende recebimento, conferência, transporte interno, abertura de volumes para a conferência aduaneira,

I - o custo de transporte da mercadoria importada até o porto ou o aeroporto alfandegado de descarga ou o ponto de fronteira alfandegado onde devam ser cumpridas as formalidades de entrada no território aduaneiro;

II - os gastos relativos à carga, à descarga e ao manuseio, associados ao transporte da mercadoria importada, até a chegada aos locais referidos no inciso I; e

III - o custo do seguro da mercadoria durante as operações referidas nos incisos I e II.

${ }^{13}$ Decreto $\mathrm{n}^{\circ}$ 6.759, art. 79: "Não integram o valor aduaneiro, segundo o método do valor de transação, desde que estejam destacados do preço efetivamente pago ou a pagar pela mercadoria importada, na respectiva documentação comprobatória (Acordo de Valoração Aduaneira, Artigo 8, parágrafo 2, aprovado pelo Decreto Legislativo no 30 , de 1994, e promulgado pelo Decreto $\mathrm{n}^{\mathrm{O}} 1.355$, de 1994):

I - os encargos relativos à construção, à instalação, à montagem, à manutenção ou à assistência técnica, relacionados com a mercadoria importada, executados após a importação; e

II - os custos de transporte e seguro, bem como os gastos associados ao transporte, incorridos no território aduaneiro, a partir dos locais referidos no inciso I do art. 77.

14 "O trabalho portuário de capatazia, estive conferência de carga, conserto de carga, bloco e vigilância de embarcações, nos portos organizados, será realizado por trabalhadores portuários com vínculo empregatício por prazo indeterminado e por trabalhadores portuários avulsos.

$\S 1^{\circ}$ Para os fins desta Lei, consideram-se:

I - capatazia: atividade de movimentação de mercadorias nas instalações dentro do porto, compreendendo o recebimento, conferência, transporte interno, abertura de volumes para a conferência aduaneira, manipulação, arrumação e entrega, bem como o carregamento e descarga de embarcações, quando efetuados por aparelhamento portuário". 
manipulação, arrumação e entrega, bem como o carregamento e descarga de embarcações, quando efetuados por aparelhamento portuário.

Ou seja, o momento de ocorrência do fato gerador, que faz surgir a relação jurídicotributária, nos termos da lei ${ }^{15}$ e da jurisprudência ${ }^{16}$ é o do desembaraço aduaneiro que ocorre anteriormente a qualquer despesa incorrida com capatazia que ocorre apenas em momento posterior à formação do valor aduaneiro.

A relação jurídico-tributária surge, dessa forma, anteriormente a qualquer desembolso relativo às despesas com capatazia que não poderão, dessa forma, compor a base de cálculo do Imposto de Importação.

Esse entendimento vai ao encontro do que dispõe o Decreto $n^{\circ} 2.498$ de 1998 que internalizou, no ordenamento jurídico brasileiro, o artigo VII do Acordo Geral sobre Tarifas e Comércio (GATT 1994) ${ }^{17}$, que dispõe que, independentemente do método de valoração utilizado, serão incluídos no valor aduaneiro o custo de transporte das mercadorias importadas até o porto ou local da importação e os gastos relativos à carga, descarga e manuseio, associados ao transporte das mercadorias importadas até o porto ou local de importação.

Dessa forma, e não havendo discordância quanto aos tratados internacionais dos quais o Brasil é signatário serem fontes formais do Direito Tributário, podemos entender que a aplicação da máscara de Klaus Vogel ao Direito interno funcionará, neste caso, para tapar as normas que disponham de modo contrário à aplicação de tais tratados, deixando visíveis apenas aquelas que estejam de acordo com o Acordo de Valoração Aduaneira.

Voltamos às lições de Luís Eduardo Schoueri, que dispôs que somente quando da existência de uma norma de Direito Tributário interno, prevendo a incidência tributária no caso e, cumulativamente, da ausência de norma de acordo de bitributação excluindo aquela tributação, é que se poderia concluir pelo nascimento da obrigação tributária no caso concreto. (SCHOUERI, 2017, p. 126).

\footnotetext{
${ }^{15}$ Decreto-Lei no 37 de 1966: "Art. 23. Quando se tratar de mercadoria despachada para consumo, considera-se ocorrido o fato gerador na data do registro, na repartição aduaneira, da declaração a que se refere o artigo 44".

${ }^{16}$ A Súmula 661 do Supremo Tribunal Federal dispõe que "Na entrada de mercadoria importada do exterior, é legítima a cobrança do ICMS por ocasião do desembaraço aduaneiro".

${ }^{17}$ Decreto $\mathrm{n}^{\circ}$ 2.498, art. 17: "No valor aduaneiro, independentemente do método de valoração utilizado, serão incluídos (parágrafo 2 do artigo 8 do Acordo de Valoração Aduaneira):

I - o custo de transporte das mercadorias importadas até o porto ou local de importação;

II - os gastos relativos a carga, descarga e manuseio associados ao transporte das mercadorias importadas até o porto ou local de importação; e

III - o custo do seguro nas operações referidas nos incisos I e II".
} 
O que nos leva à conclusão de que o parágrafo $3^{\circ}$, do art. $4^{\circ}$, da Instrução Normativa

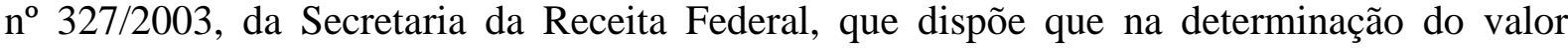
aduaneiro, independentemente do método de valoração aduaneira utilizado, serão incluídos os gastos relativos à descarga da mercadoria do veículo de transporte internacional no território nacional no valor aduaneiro restará inaplicável no presente caso, tendo em vista que contraria frontalmente o Acordo de Valoração Aduaneira, assinado pelo Brasil, e internalizado pelo Decreto nº 2.498 de 1998 .

Mister se faz ressaltar que, o Superior Tribunal de Justiça, segue o entendimento aqui esposado, conforme pode-se destacar a partir de acórdãos recentes. É o caso de decisão publicada em 04 de maio de 2017, no julgamento do Recurso Especial no 1.626 .971 - SC, cuja relatora foi a Ministra Assusete Magalhães, decidiu-se que os gastos tidos após a chegada das mercadorias no porto, em especial com capatazia, não se incluem no valor aduaneiro, base de cálculo do Imposto de Importação, segue ementa ${ }^{18}$ :

TRIBUTÁRIO E PROCESSUAL CIVIL. RECURSO ESPECIAL (...) IMPOSTO DE IMPORTAÇÃO. BASE DE CÁLCULO. VALOR ADUANEIRO. DESPESAS DE CAPATAZIA. INCLUSÃO. IMPOSSIBILIDADE. ART. $4^{\circ}, \S 3^{\circ}$, DA IN SRF 327/2003. ILEGALIDADE. RECURSO ESPECIAL PARCIALMENTE CONHECIDO, E, NESSA PARTE, IMPROVIDO (...) IV . Na forma da jurisprudência do STJ, o art. $4^{o}$, § $3^{\circ}$, da IN/SRF 327/2003, ao incluir os gastos de capatazia, efetuados após a chegada da mercadoria no país importador, na constituição do valor aduaneiro, para fins de cobrança do Imposto de Importação, desbordou de seus limites de regulamentação da legislação federal. Precedentes: STJ, REsp 1.239.625/SC, Rel. Ministro BENEDITO GONÇALVES, PRIMEIRA TURMA, DJe de 04/11/2014; AgRg no REsp 1.434.650/CE, Rel. Ministro HERMAN BENJAMIN, SEGUNDA TURMA, DJe de 30/06/2015; AgInt no REsp 1.566.410/SC, Rel. Ministro BENEDITO GONÇALVES, PRIMEIRA TURMA, DJe de 27/10/2016; REsp 1.528.204/SC, Rel. p/ acórdão Ministro MAURO CAMPBELL MARQUES, SEGUNDA TURMA, DJe de 19/04/2017. V. Os serviços

\footnotetext{
18 BRASIL. Superior Tribunal de Justiça. Recurso Especial no 1.626 .971 - SC (2016/0246580-5). Relatora Ministra Assusete Magalhães. Data de Julgamento: 25/04/2017, T2 - Segunda Turma, Data de Publicação: DJe 04/05/2017 Disponível em: https://stj.jusbrasil.com.br/jurisprudencia/465718745/recurso-especial-resp-1626971sc-2016-0246580-5. Acesso em: 9 dez. 2017.
} 
de capatazia encontram lastro normativo constitucional $e$ infraconstitucional idôneo para a incidência de outro imposto, de competência dos Municípios, qual seja, o imposto sobre serviços de qualquer natureza, como se constata por simples leitura do art. 156, III, da CF/88 c/c o item 87 da Lista de Serviços a que se refere o art. $8^{\circ}$ do Decreto-lei 406/68, correspondente ao item 20 e subitens 20.01 e 20.02 da Lista de Serviços a que se refere o art. $1^{\circ}$ da Lei Complementar 116/2003, que contemplam, como fato gerador do ISSQN, a prestação de serviços de capatazia em portos e aeroportos. VI. Recurso Especial parcialmente conhecido, e, nessa parte, improvido. (STJ - REsp: 1626971 SC 2016/0246580-5, Relator: Ministra ASSUSETE MAGALHÃES, Data de Julgamento: 25/04/2017, T2 - SEGUNDA TURMA, Data de Publicação: DJe 04/05/2017).

Há diversas decisões do STJ neste sentido e não colacionaremos todas para não incorrer em prolixidade, o que importa saber, neste momento, é que de acordo com o entendimento da Segunda Turma do STJ, somente poderiam ser incluídos no valor aduaneiro, que é a base de cálculo do Imposto de Importação, os gastos incorridos até a chegada da mercadoria ao porto do país de importação. De forma que os valores incorridos após a chegada da mercadoria ao porto do país de importação não podem compor o valor aduaneiro, pois tratarse-iam de elementos estranhos à operação de importação em si.

Toda via, faz-se válido esposar recente Acórdão proferido pela Primeira Turma do STJ, que consolidou o entendimento do Tribunal de que as despesas com capatazia não devem ser incluídas na base de cálculo do Imposto de Importação ${ }^{19}$ :

TRIBUTÁRIO. PROCESSO CIVIL. DEFICIÊNCIA RECURSAL. SÚMULA 284/STF. IMPOSTO DE IMPORTAÇÃO. BASE DE CÁLCULO. VALOR ADUANEIRO. DESPESAS DE CAPATAZIA. INCLUSÃO. IMPOSSIBILIDADE. ART. $4^{\circ}, \S 3^{\circ}$, DA IN SRF 327/2003. ILEGALIDADE. RECURSO MANIFESTAMENTE IMPROCEDENTE. MULTA. IMPOSIÇÃO.

(...)

\footnotetext{
${ }^{19}$ BRASIL. Superior Tribunal de Justiça. Recurso Especial no 1.693.873 - SC (2017/0209409-6) Relator Ministro Sérgio Kukina. Data de Julgamento: 21/06/2018, T1 - Primeira Turma, Data de Publicação: DJe 28/06/2018. Disponível em: <http://www.stj.jus.br/SCON/jurisprudencia/toc.jsp?livre=1693873\&\&tipo_visualizacao=RESUMO\&b=ACO > Acesso em: 23 ago. 2018.
} 
2. As despesas de capatazia não devem ser incluídas no valor aduaneiro que compõe a base de cálculo do imposto de importação, tendo em vista que o Acordo de Valoração Aduaneiro e o Decreto n ${ }^{\circ}$ 6.759/2009, ao mencionar os gastos a serem computados no valor aduaneiro, refere-se a despesas com carga, descarga e manuseio das mercadorias importadas até o porto alfandegado. A Instrução Normativa $\mathrm{n}^{\circ}$ $327 / 2003$, por seu turno, refere-se a valores relativos à descarga das mercadorias importadas, já no território nacional. 3. O STJ entende que "a Instrução Normativa $n^{\circ} 327 / 03$ da SRF, ao permitir, em seu artigo $4^{\circ}, \S 3^{\circ}$, que se computem os gastos com descarga da mercadoria no território nacional no valor aduaneiro, desrespeita os limites impostos pelo Acordo de Valoração Aduaneira e pelo Decreto $n^{\circ} \quad 6.759 / 09$, tendo em vista que a realização de tais procedimentos de movimentação de mercadorias ocorre apenas após a chegada da embarcação, ou seja, após a sua chegada ao porto alfandegado" (REsp 1.239.625/SC, Rel. Ministro Benedito Gonçalves, Primeira Turma, DJe 4.11.2014). 4. Tendo em vista que aviado agravo interno contra decisão que se amparou no posicionamento tranquilo de ambas as Turmas da Seção de Direito Público desta Corte Superior sobre o tema em debate, é de se reconhecer a manifesta improcedência do agravo, sendo, pois, aplicável a multa prevista no $\S 4^{\circ}$ do art. 1.021 do CPC/2015. 5. Agravo interno parcialmente conhecido e, nessa parte, não provido, com imposição de multa.

Demonstramos, dessa forma, que o STJ já tem entendimento consolidado sobre a ilegalidade do art. $4^{\circ}, \S 3^{\circ}$ da Instrução Normativa $n^{\circ} 327$ de 2003 sendo, portanto, ilegal, a inclusão das despesas com capatazia na base de cálculo do Imposto de Importação, por violar os limites impostos pelo Acordo de Valoração Aduaneira e pelo Decreto 6.759 de 2009, que o implementa.

Superadas as questões doutrinarias e jurisprudenciais acerca da temática, podemos dedicar a parte final do presente trabalho, mesmo que de forma breve, às questões práticas acerca da temática, em especial às questões relacionadas à identificação das despesas com capatazia e ao cálculo do valor a ser restituído.

Os valores relativos às despesas com capatazia podem ser encontrados a partir do cruzamento de dados das planilhas de relatório de preço de transferência e de relatório ad hoc, extraídas do Sistema Integrado de Comércio Exterior (SISCOMEX). O relatório preço de 
transferência informa, de forma detalhada, todas as importações de determinado período (no caso deverá ser feita a extração das importações realizadas nos últimos 5 anos) e o relatório $a d$ hoc traz, também de forma detalhada, todos os acréscimos incorridos no mesmo período para as importações. Dessa forma, pode-se chegar a um work paper com todas as Declarações de Importação cujos valores estão majorados pelas despesas com capatazia.

Para o cálculo do valor a ser restituído a título de Imposto de Importação incidente sobre o Valor Aduaneiro majorado pelas despesas com capatazia pode-se fazer uma operação matemática simples: Somam-se os valores relativos ao frete, ao seguro, e ao FOB, para chegar ao valor aduaneiro. Em seguida, subtrai-se o valor dos acréscimos de despesas com capatazia deste. A partir daí tem-se o valor aduaneiro sem acréscimos de despesas com capatazia e podese fazer incidir a alíquota do Imposto de Importação sobre a base correta (que não é composta pelos mencionados acréscimos). Por fim, basta subtrair do valor a recolher de Imposto de Importação o valor a recolher do Imposto de Importação sem capatazia. A diferença será o valor a restituir.

A equação poderia ser representada pela seguinte fórmula:

Valor a Recolher II - [(Frete + Seguro + FOB - Despesas com Capatazia $) *$ Alíquota II] = Valor a restituir

Dessa forma, somando-se o valor a restituir relativo à todas as operações dos últimos 5 anos, chegar-se-á ao valor total a restituir.

\section{CONSIDERAÇÕES FINAIS}

Para demonstrar a ilegalidade da inclusão das despesas com capatazia na base de cálculo do Imposto de Importação prevista no que parágrafo $3^{\circ}$ do art. $4^{\circ}$ da Instrução Normativa n $327 / 2003$ da Secretaria da Receita Federal, fizemos um estudo fizemos, primeiramente, um estudo sobre as fontes do Direito, tanto sob a ótica da Teoria Geral do Direito quanto sob a ótica do Direito Tributário e demonstramos que os tratados internacionais que o Brasil é signatário são fontes formais do Direito Tributário. Demonstramos, também, que a leis internas que conflitarem com disposições de tratados internacionais deverão ter sua aplicabilidade suspensa (por aplicação da Teoria da Máscara de Klaus Vogel), devendo prevalecer, portanto, o que previr o tratado internacional.

Em seguida tratamos da Regra Matriz de Incidência Tributária, dando especial enfoque aos seus aspectos temporal e quantitativo, tendo em vista que estes são essenciais para a 
resolução da questão, e pudemos demonstrar que, a despeito de divergências doutrinais, a jurisprudência entende que o aspecto temporal do Imposto de Importação seria o momento do desembaraço aduaneiro, sendo, portanto, neste momento que se formaria o valor aduaneiro e que surgiria a relação jurídico-tributária.

$\mathrm{Na}$ última parte do trabalho tratamos da questão das despesas com capatazia propriamente dita, explicando como surgiu a controvérsia, expusemos nosso entendimento acerca da temática sob a ótica da melhor doutrina, das leis e dos decretos que versam sobre a questão, e da jurisprudência consolidada no STJ para chegar a conclusão pela ilegalidade da inclusão das despesas com capatazia na base de cálculo do Imposto de Importação. Após firmado esse ponto, pudemos tratar dos aspectos práticos relacionados à identificação das despesas com capatazia e ao procedimento para cálculo do valor a ser restituído.

\section{REFERÊNCIAS}

ATALIBA, Geraldo. Hipótese de incidência tributária. 6. ed. São Paulo: Malheiros, 2016.

BECHO, Renato Lopes. Lições de direito tributário. 3. ed. São Paulo: Saraiva, 2015.

BRASIL. Constituição Federal de 1988. Constituição da República Federativa do Brasil de 1988.

http://www.planalto.gov.br/ccivil_03/constituicao/constituicaocompilado.htm. Acesso em: 21 nov.2017.

Lei $\mathrm{n}^{\circ}$ 5.172, de 25 de outubro de 1966. Dispõe sobre o Sistema Tributário Nacional e institui normas gerais de direito tributário aplicáveis à União, Estados e Municípios. Disponível em: http://www.planalto.gov.br/ccivil_03/leis/L5172Compilado.htm. Acesso em: 21 nov. 2017.

Lei $n^{\circ} 12.815$, de 5 de junho de 2013. Dispõe sobrea exploração direta e indireta pela União de portos e instalações portuárias e sobre as atividades desempenhadas pelos operadores portuários. Disponível em: http://www.planalto.gov.br/ccivil_03/_ato20112014/2013/lei/112815.htm. Acesso em: 07 dez. 2017.

Decreto n ${ }^{\circ} 2.498$, de 13 de fevereiro de 1998. Dispõe sobre a Implementação do Artigo VII do Acordo Geral sobre Tarifas e Comércio - GATT 1994. Disponível em: http://www.planalto.gov.br/ccivil_03/decreto/d2498.htm. Acesso em: 9 dez. 2017.

Decreto $\mathrm{n}^{\circ}$ 6.759, de 5 de fevereiro de 2009. Regulamenta a administração das atividades aduaneiras, e a fiscalização, o controle e a tributação das operações de comércio exterior. Disponível em: http://www.planalto.gov.br/ccivil_03/_ato20072010/2009/decreto/d6759.htm. Acesso em: 21 nov. 2017.

Decreto $\mathrm{n}^{\circ} 7.030$, de 14 de dezembro de 2009. Promulga a Convenção de Viena sobre o Direito dos Tratados. Disponível em: http://www.planalto.gov.br/ccivil_03/_ato20072010/2009/decreto/d7030.htm Acesso em: 21 nov. 2017. 
Decreto-Lei $\mathrm{n}^{\circ}$ 4.657, de 4 de setembro de 1942. Lei de Introdução às Normas do Direito Brasileiro. Disponível em: http://www.planalto.gov.br/ccivil_03/decretolei/Del4657.htm. Acesso em: 21 nov. 2017.

Decreto-Lei no , de 18 de novembro de 1966. Dispõe sobre o Imposto de Importação, reorganiza os serviços aduaneiros e dá outras providências. Disponível em: http://www.planalto.gov.br/ccivil_03/decreto-lei/Del0037compilado.htm. Acesso em: 21 nov. 2017.

Instrução Normativa da Secretaria da Receita Federal no 327, de 09 de maio de 2003. Estabelece normas e procedimentos para a declaração e o controle do valor aduaneiro de mercadoria importada. Disponível em: http://normas.receita.fazenda.gov.br/sijut2consulta/link.action?visao=anotado\&idAto=15217. Acesso em: 21 nov. 2017.

Supremo Tribunal Federal. Súmula $\mathrm{n}^{\mathrm{o}}$ 661. Disponível em: http://www.stf.jus.br/portal/cms/verTexto.asp?servico=jurisprudenciaSumula. Acesso em: 21 nov. 2017.

Superior Tribunal de Justiça. Recurso Especial nº 1.626.971 - SC (2016/0246580-5,). Relatora Ministra Assusete Magalhães. Data de Julgamento: 25/04/2017, T2 - Segunda Turma, Data de Publicação: DJe 04/05/2017 Disponível em: https://stj.jusbrasil.com.br/jurisprudencia/465718745/recurso-especial-resp-1626971-sc-20160246580-5. Acesso em: 9 dez. 2017.

BRASIL. Superior Tribunal de Justiça. Recurso Especial nº 1.693.873 - SC (2017/0209409-6) Relator Ministro Sérgio Kukina. Data de Julgamento: 21/06/2018, T1 - Primeira Turma, Data de Publicação: DJe 28/06/2018. Disponível em: http://www.stj.jus.br/SCON/jurisprudencia/toc.jsp?livre=1693873\&\&tipo_visualizacao=RES UMO\&b=ACO . Acesso em: 23 ago. 2018.

CARVALHO, Paulo de Barros. Curso de direito tributário. 26. ed. São Paulo: Saraiva, 2015.

DINIZ, Maria Helena. Compêndio de introdução à ciência do direito. 26. ed. São Paulo: Saraiva, 2017.

GUSMÃO, Paulo Dourado de. Introdução ao estudo do direito. 48. ed. rev. Rio de Janeiro: Forense, 2015.

KELSEN, Hans. Teoria pura do direito. trad. João Baptista Machado. 6. ed. São Paulo: Martins Fontes, 1998.

MONTEIRO, Alexandre Luiz Moraes do Rêgo. Direito tributário internacional: A arbitragem nos acordos de bitributação celebrados pelo Brasil. Série Doutrina Tributária Vol. XX. São Paulo: Quartier Latin, 2016.

NADER, Paulo. Introdução ao estudo do Direito. 39. ed. rev. e atual. Rio de Janeiri: Foresnse, 2017.

NUNES, Rizzatto. Manual de introdução ao estudo do direito. 14. ed. São Paulo: Saraiva, 2016.

REALE, Miguel. Lições preliminares de direito. 27. ed. São Paulo: Saraiva, 2002.

SCHOUERI, Luís Eduardo. Direito Tributário. 7. ed. São Paulo: Saraiva, 2017. 
SILVEIRA, Ricardo Maitto da. O escopo pessoal dos acordos internacionais contra a bitributação: Regimes fiscais especiais, conflitos de qualificação e casos triangulares. Série Doutrina Tributária Vol. XIX. São Paulo: Quartier Latin, 2016. 